\title{
Towards an understanding of dialectical authenticity of historic landscapes in
}

\section{China}

Chen Yang, Gillian Lawson, Jeannie Sim, Feng Han

\begin{abstract}
The purpose of this article is to explore the contemporary stakeholders' understanding of authenticity for historic landscapes in China, with a focus on an appropriate conservation and management strategy. A World Heritage site, Slender West Lake Scenic and Historic Interest Area, was examined as a case study. It was found that the authenticity of historic landscapes is a dialectical concept in China. The originality of fabric, the representation of intangible values, and the social engagement, were considered as three major indicators of authenticity by various stakeholders, but choosing the appropriate indicator was significantly influenced by specific social, political and economic powers. The concept of dialectical authenticity has been influenced by native Chinese philosophies and the cultural characteristic of naïve dialecticism, which could partly explain the contemporary conservation practice in China. The case study also demonstrates that creative reconstruction has always been an important cultural practice in the history of Slender West Lake and today. However, the superficial application of this cultural feature may cause problems for landscape conservation. The interrogation of the concept of dialectical authenticity provided some implications for conservation research and practices.
\end{abstract}

KEYWORDS historic landscape, authenticity, dialectical authenticity, creative reconstruction, Slender West Lake, China 


\section{1 | INTRODUCTION}

The notion of historic landscape refers landscape environments of cultural and historic significance, both in tangible and intangible dimensions (Clark et al., 2004). Historic landscapes can be understood as the layered time dimension of cultural landscapes, they are "illustrative of the evolution of human society and settlement over time, under the influence of the physical constraints and/or opportunities presented by their natural environment and of successive social, economic and cultural forces, both external and internal" (UNESCO World Heritage Center 2017; Skogheim et al., 2018). The conservation of historic landscape has become a global issue in the 21 st century due to the increasing pace of landscape changes and the loss of historic information (Eetvelde \& Antrop, 2004). Each cultural group needs to identify their own understanding of historic landscape and develop contextualised conservation and management strategies. The object of historic landscape conservation is the areas containing natural, seminatural and cultural features, and all aspects of the present-day landscape including changes and earlier landscapes should be considered in conservation (Clark et al., 2004). Therefore, historic landscapes are different from other cultural heritage types, and it is necessary to carry out special research on its authenticity.

The conservation of historic landscapes has become a contested field in China. The conflict between national policies and local practices are becoming more severe over the past decade. At the national level, the primary document of historic conservation, the Principles for the Conservation of Heritage in China (The Chinese Principles) is aligned with most international conservation guidelines, which does not accept large-scale reconstruction. At the local level, however, rebuilding historic landscapes has been used as the main approach for 
conservation. For example, Shanhaiguan District in Qinhuangdao, Hebei province is a Statelisted Famous Historic and Cultural City [1] in China. The local government started to reconstruct 6 kilometres of Great Wall within this district to "return" the historic landscape of the Ming and Qing dynasties (1368-1932 CE). Such a large-scale reconstruction without reliable historical records challenged most international conservation principles. Although the reconstruction of the historical environment can promote local tourism and improve urban environment, reconstruction without adequate historical information not only caused damage to historical evidence, but also produced problematic interpretations of historical conditions. It is necessary to build a better understanding of the complicated phenomena in the conservation of historic landscapes in China, to establish an appropriate theoretical framework and corresponding action guidelines.

The understanding of authenticity plays a fundamental role in all research and practices of the cultural heritage (UNESCO World Heritage Center, 2017). There have been some intense debates on authenticity internationally over the past fifty years, which have been enabling for the formulations of conservation theory and practices (Araoz, 2013). The theory of heritage authenticity has also been examined in China, but there are relatively few in-depth studies on the perception of authenticity among different stakeholders. As the stakeholder group contains important practitioners of heritage conservation, their understandings and interpretations of the authenticity is crucial to the practical work of historic landscape conservation. Whether the concept of authenticity exists in local conservation practices, and in what form it exists, is an important and urgent research problem. Therefore, this article aims to explore and then interrogate the contemporary stakeholders' understandings of authenticity in China, with the 
focus on establishing an appropriate attitude for conservation and management practices.

\section{2 | AUTHENTICITY OF CULTURAL HERITAGE AND HISTORIC}

\section{LANDSCAPES}

Authenticity and integrity are the two most important concepts of cultural heritage evaluation.

The former refers to the ability of an attribute to convey its value and significance, and the later refers to the ability of an attribute to maintain and sustain this value (Stovel, 2007). The notion of authenticity in the cultural heritage field can be traced back to the early 20th century (Starn, 2002). The provenance of the word "authenticity" was in the museum world of Western Europe (Trilling, 1972). Generally, authenticity refers to that the object is a genuine representation of what it claims to be (Stovel, 2007). Over the past century, especially after heritage conservation became a global issue in the 1960 s, different concepts of authenticity have been created to address the issues for different heritage categories in different cultural contexts (Starn, 2002). In this research, three models of authenticity were used to set up a theoretical framework for the exploration of Chinese situation.

Firstly, the model of material-based authenticity was a fundamental concept created in the middle 19th century mainly for architectural heritage (Araoz, 2013). It assumes that there is something inherently "authentic". The term "authenticity" poses as objectivism, holding the power of "the truth" (Taylor, 2001). The originality of physical settings of a heritage site, including its design, material, workmanship, use, and settings, were considered as the main indicators for authenticity (Araoz, 2013). In terms of conservation practice, therefore, reconstruction is generally not acceptable (Article 9) (ICOMOS, 1964), and only "anestyplosis" 
[2] is permitted.

The second model is the value-based authenticity generated from discussions between the East and West in the 1990s. Many cultural heritage sites in non-Western cultures did not suit the model of material-based authenticity, because of the differences in their natural and cultural contexts (Araoz, 2013). Reconstruction is acceptable in many cultures if there are enough historic records of the site (Jerome, 2008). In Japan, for example, the tradition of "Sengu" involves periodically dismantling the Shinto temple to replace deteriorated fabric, and then rebuilding it using the original technology (Kobyiński, 2006). The Nara Document on Authenticity (The Nara Document) (ICOMOS, 1994) was the first international document to recognise the cultural difference of authenticity: Authenticity is in practice never absolute, always relative (Lowenthal, 1995). The value-based authenticity assumes that it is the value indicated by the heritage that is the essential attribute of authenticity, rather than the physical settings (Ahmad, 2006). In practice, some cultures prefer a complete image of the original shape to fully represent meanings and values of the heritage place, even with the use of new material. Therefore, the testing of authenticity needs to cover the intangible attributes of cultural heritage, such as sense of place, customs, and spiritual meanings (Ahmad, 2006). In addition, the valuebased model not only places the judgement of authenticity in a specific cultural context, but also pays more attention to the time dimension and evolution of cultural heritage. The changes over time considering the setting, function, spirit and feeling and so forth, should be considered as important heritage attributes with the value-based authenticity model (Jerome, 2008).

The third perspective on authenticity is the New Heritage concept, which assumes that 
heritage is valuable for matters in contemporary society, such as conflict resolution, economic regeneration, education for citizenship, and sustainable development (Dawdy, 2009; Loulanski, 2006). Like the value-based authenticity, the New Heritage concept also maintains that authenticity resides in the cultural meanings and values humans invest in the environment, not in their physical substance (Araoz, 2011; Fairclough, 2009; Fojut, 2009; Loulanski, 2006). In practice, however, the New Heritage concept provides a more flexible framework for social engagement. It maintains that the act of changing, rebuilding and replacing a heritage feature is in all forms interpreting, using and transforming heritage (Holtorf, 2006). Conservation should shift the focus from protection towards the management of change and creation (Poulios, 2010). In recent years, international heritage communities have increasingly supported the reconstruction of damaged World Heritage properties (Khalaf, 2018). As cultural heritage undergoes a continuous process of change, the creation and reconstruction can be a layer of significance that is authentic of its period (Khalaf, 2018). Meanwhile, the approach of Historic Urban Landscape (HUL) also maintains that change to city form will be inevitable, and critical to HUL is managing these changes, recognising heritage is of vital importance for cities because it can be used as a key resource in enhancing liveability in urban areas (Taylor, 2016).

In practice, these models of authenticity have been applied to different heritage types. For example, the first model is often used for archaeological sites, monuments, and stone buildings (Zhang \& Dong, 2018). The latter two have been used more often in heritage sites with larger scales, more stakeholders, and more obvious and rapid changes, such as parks, rural areas, and historical urban districts. Historic landscapes have special requirements for testing authenticity due to its distinctive features. On the one hand, historic landscapes normally contain many 
living components such as plants and animals. Therefore, rather than focusing on the intactness of individual components, the landscape character has been deemed as an essential factor of authenticity for historic landscapes (Rössler, 2008). The changing but continuing character of a historic landscape is the most important indicator of authenticity and should be protected as the essential object in conservation practices (Fairclough, 2001; Macinnes, 2004; Turner, 2006). Because of its conceptual comprehensiveness and clear workflow, the Landscape Character Assessment guidance designed by Cary Swanwick (2002) has become a powerful tool for identifying and examining landscape heritage since its publication in 2002. This paper applied this guidance to examine the authenticity of Chinese historic landscapes.

On the other hand, the authenticity of historic landscapes is dynamic and needs to be periodically examined. The authenticity of historic landscapes lies in the dynamic interactions between nature and human beings that shape the landscape (Denyer, 2005; Mitchell, 1994). Both tangible and intangible components of a historic landscape have the capacity to evolve, thus its authenticity may also change (Denyer, 2005). Local communities' attitudes towards the landscape, including their knowledge and values established during the continual interactions within the landscape are the essential attributes for authenticity. Therefore, the understandings of authenticity need to be periodically examined and interpreted within specific cultural context to get appropriate strategies for cultural continuity.

In China, historic landscape is an arising research field in cultural heritage research. The concept of historic landscapes, the authenticity and conservation strategies have become hot topics in recent decades (Han, 2012). Many researchers have examined the concept of 
authenticity in the context of Chinese heritage conservation. They have identified the differences between international conservation principles and local applications (Zhang, 2010; Zhu, 2015). The study of heritage authenticity mainly focused on architectural heritage (Chen, 2005; Lu, 2006; Lin, 2007), which critically examined the practices of heritage reconstruction and imitating ancient buildings in China (Ruan \& Lin, 2003). The authenticity in urban heritage and tourist experiences were also examined (Liao et al., 2009; Atwal \& Williams, 2011; Feng \& Sha, 2007; Yang \& Wall, 2010). However, there are rarely studies about the different stakeholders' perceptions of authenticity in historic landscapes. Identifying and interpreting stakeholders' perceptions can help us to understand the mechanism behind local conservation activities and then contribute to practical guidance.

\section{3 | METHODS: A CASE STUDY OF SLENDER WEST LAKE}

\section{1 | Study area - Slender West Lake Scenic and Historic Interest Area}

This research involved a case study with a typical historic landscape in China - Slender West Lake Scenic and Historic Interest Area [3]. Slender West Lake is located in Yangzhou City, Jiangsu Province (Figure 1). "Slender West Lake and the Historic Urban Area in Yangzhou" was listed on the Tentative World Heritage List of China in 2006 and 2012. It was then inscribed on the World Heritage List as part of the Grand Canal World Heritage site in 2014. The protected area covers $12.23 \mathrm{~km}^{2}$, and includes Slender West Lake historic landscape and the archaeological site of Yangzhou City. This research focuses on the Slender West Lake historic landscape, which is $0.79 \mathrm{~km}^{2}$. 

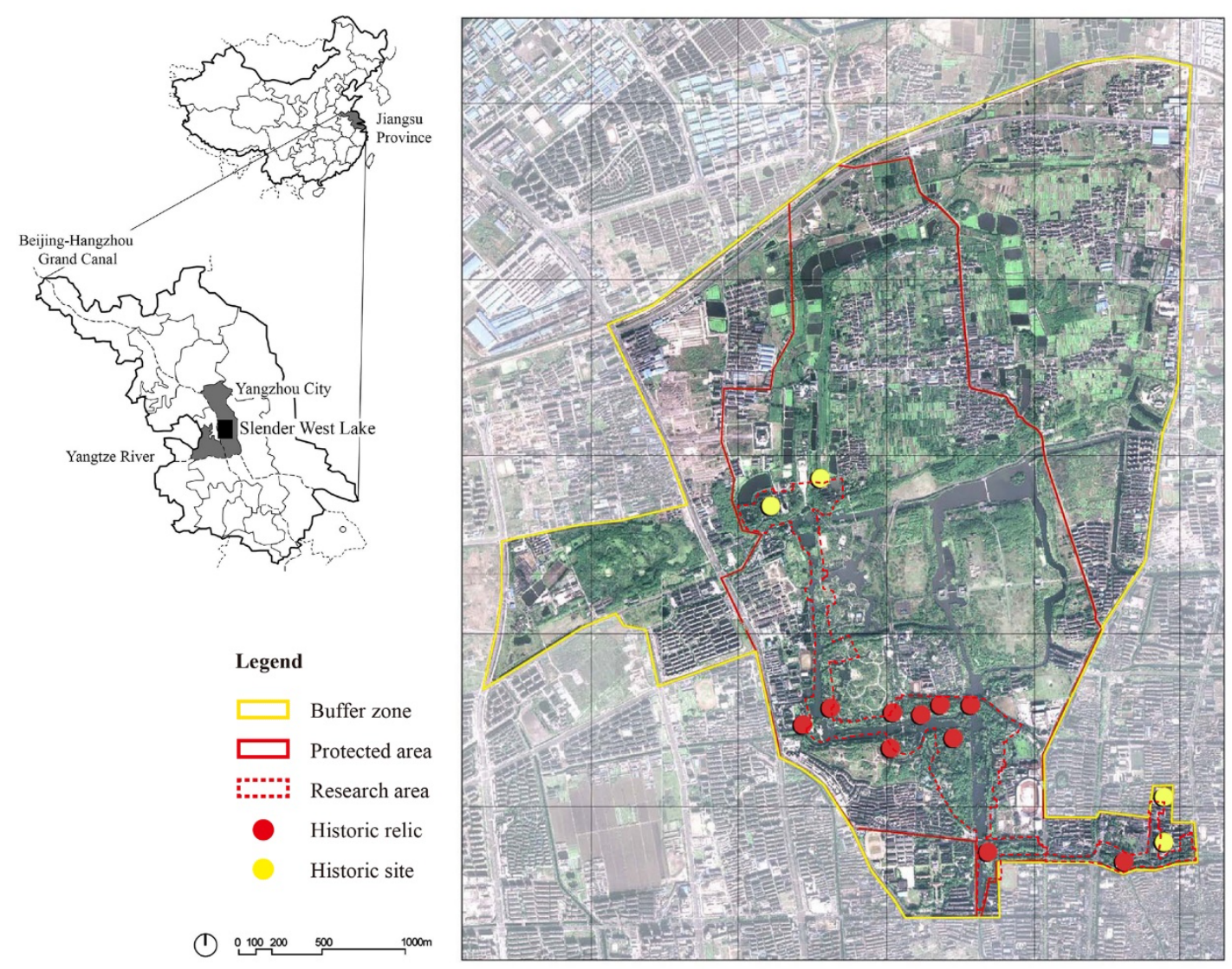

Figure 1. Location of Slender West Lake

Slender West Lake was selected as a case for three reasons. Firstly, it demonstrates the traditional Chinese way of seeing landscapes. Slender West Lake is a designed garden landscape mainly built by salt merchants in Yangzhou between 1755 and 1795 CE (Qing dynasty) (Figure 2). It reflects many characteristics of traditional Chinese landscapes, such as highly symbolic meanings, the philosophy of the "oneness of nature and human beings", and the rich humanistic attachment to natural features. Secondly, Slender West Lake also demonstrates the contemporary political, economic, and social contexts in China. As a national level Scenic and Historic Interest Area and an important tourist destination in China, the case of Slender West Lake demonstrates the characteristics of the conservation and management system at the national and local levels. The strategies and methods used in its conservation practices are 
representative, and its various types of stakeholders can also reflect the features of China's historical landscapes. Thirdly, Slender West Lake contains historic sites with different conditions of intactness and completeness, which provide an appropriate case to examine the shared understandings of authenticity in China. Therefore, Slender West Lake provides a rich context to address research questions that are relevant from both theoretical and managerial perspectives.

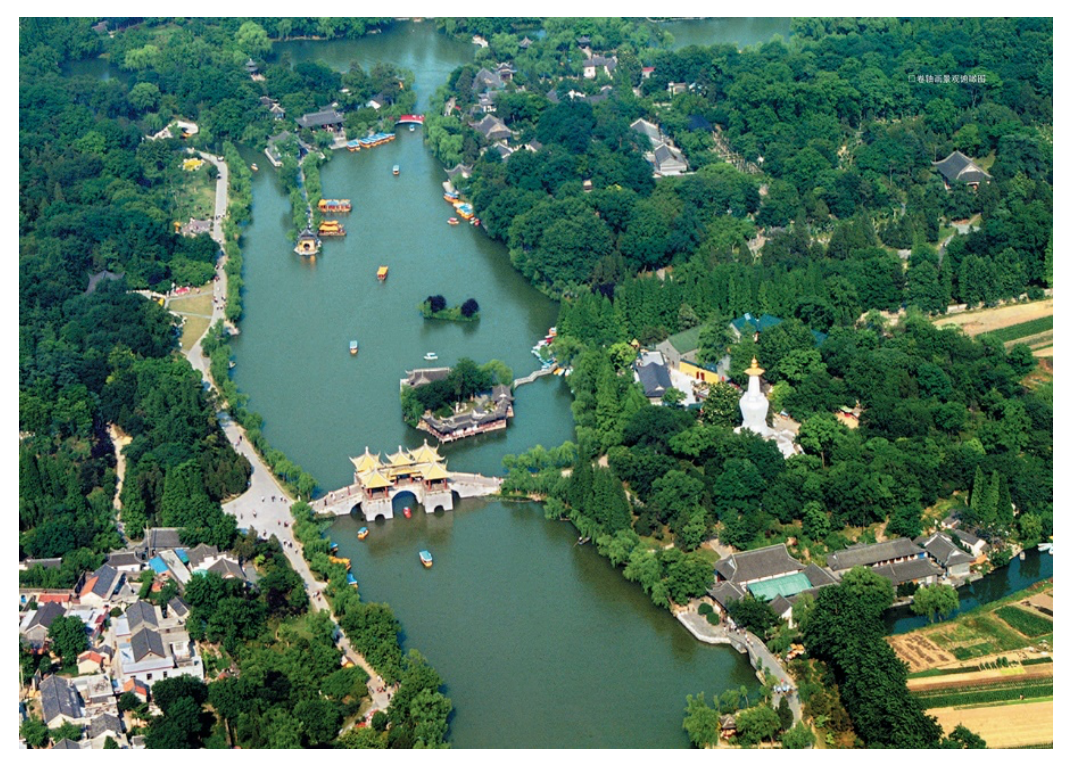

Figure 2. View of Slender West Lake, 2009, photographed by Yongkuan Mao

\subsection{Data collection and analysis}

This research included three major phases (Figure 3). Firstly, it maintained that the condition of a historic landscape is the result of the conservation practices guided by specific understandings of authenticity. Therefore, to reveal the local concepts of authenticity, the current condition of Slender West Lake was examined through applying a Landscape Character Assessment (LCA) guidance (Swanwick, 2002). Four major steps of an LCA, including "defining scope", “desk study", "field survey", and "classification and description", were 
conducted to identify both the historical character and the current character of Slender West

Lake. The documentary evidence, such as historical archives and paintings, ancient poems, and the local chronology, were collected from local management authorities. Content analysis methods were used to identify the historical character of Slender West Lake from these documents. Landscape features, characteristics, and patterns were identified from paintings, poems, and other types of images and textual materials. As a designed landscape, the organisation and combination of garden features including landforms, water, buildings, and trees were examined from the historical representations. With the support of an NVivo 12.1 software (QSR International, Melbourne, VIC, Australia), an inductive method was applied to identify and summarise the main historical characters of Slender West Lake and the contributing landscape features. For example, the historical character and the contributing landscape features of a site called Meiling Chunshen (Plum Ridge in Deep Spring) was identified from different types of documentary evidence (Figure 4, Table 1). Based on the understanding of the historical character, the current landscape was examined through site observations, in which sketches, notes, and photographs were used to record the condition of different landscape sites. The main characters of landscape sites, and their contributing features, such as buildings, plants, water, landform, and their patterns were recorded and described by notes and images. The intangible aspects of landscape sites, including the traditional knowledge, activities and spiritual connections were also recorded if they are demonstrated and interpreted in Slender West Lake today. A comparison between the historical and current characters of Slender West Lake was then made to reveal the state of authenticity. 
STEP 1 Landscape Character Assessment
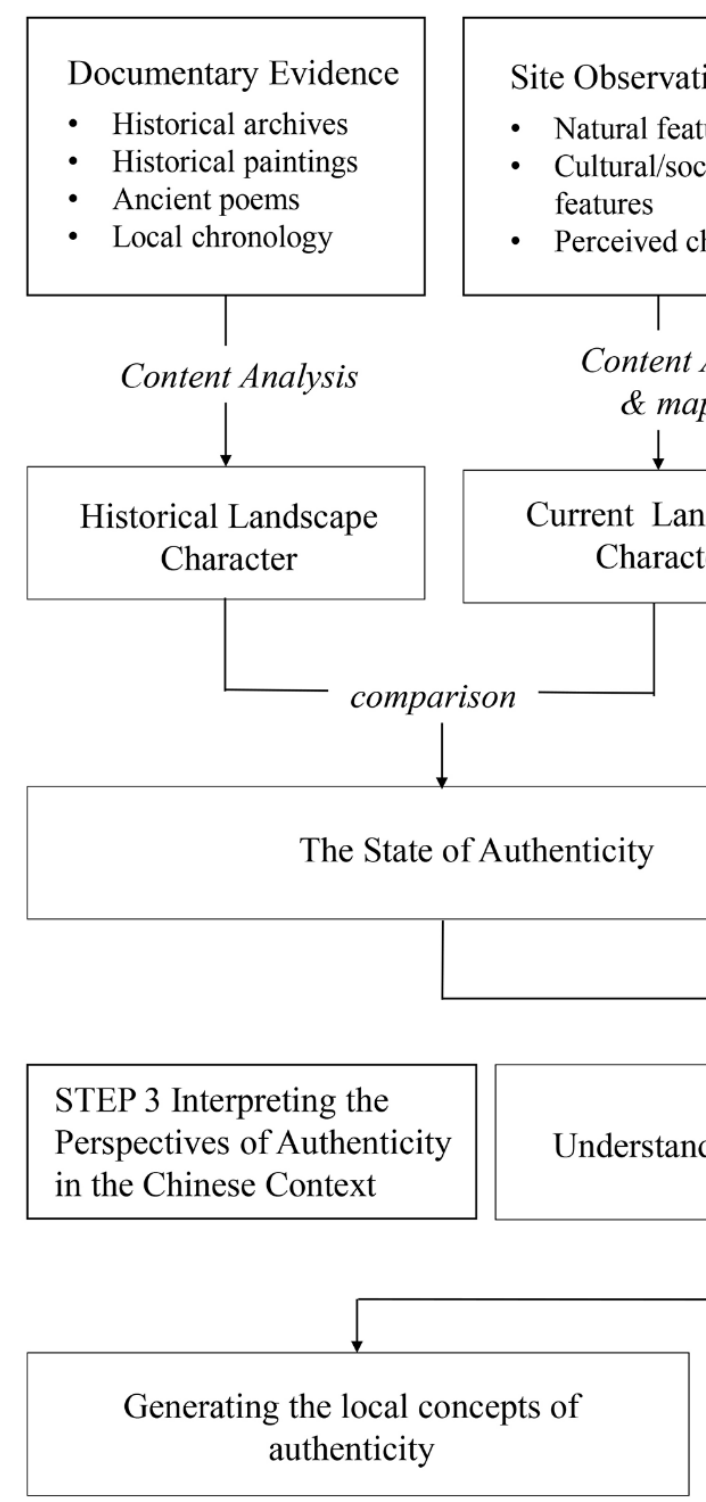

Current Landscape Character

- Natural features

- Cultural/social features

- Perceived character \& mapping $\downarrow$

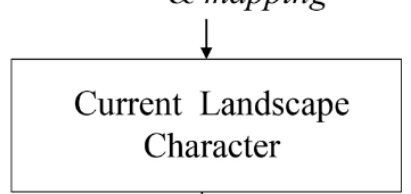

STEP 2 Interview

In-depth Interview

- Park manager

- Heritage expert

- Landscape developer

- Landscape historian

- Tour organiser

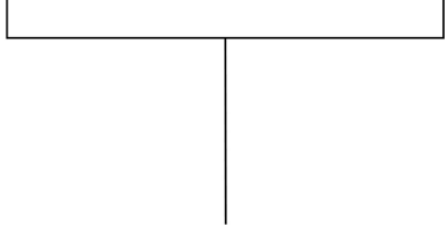

Content Analysis

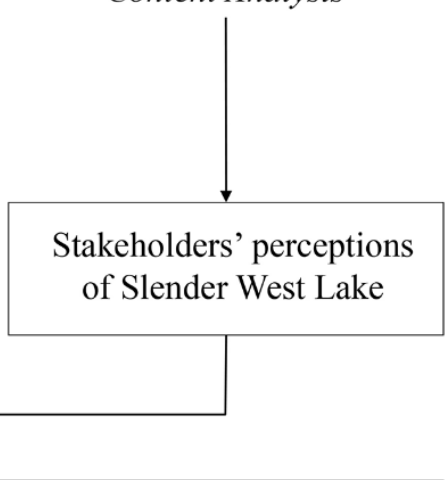

Stakeholders' perceptions of Slender West Lake

Figure 3. The work flow of the case study of Slender West Lake 


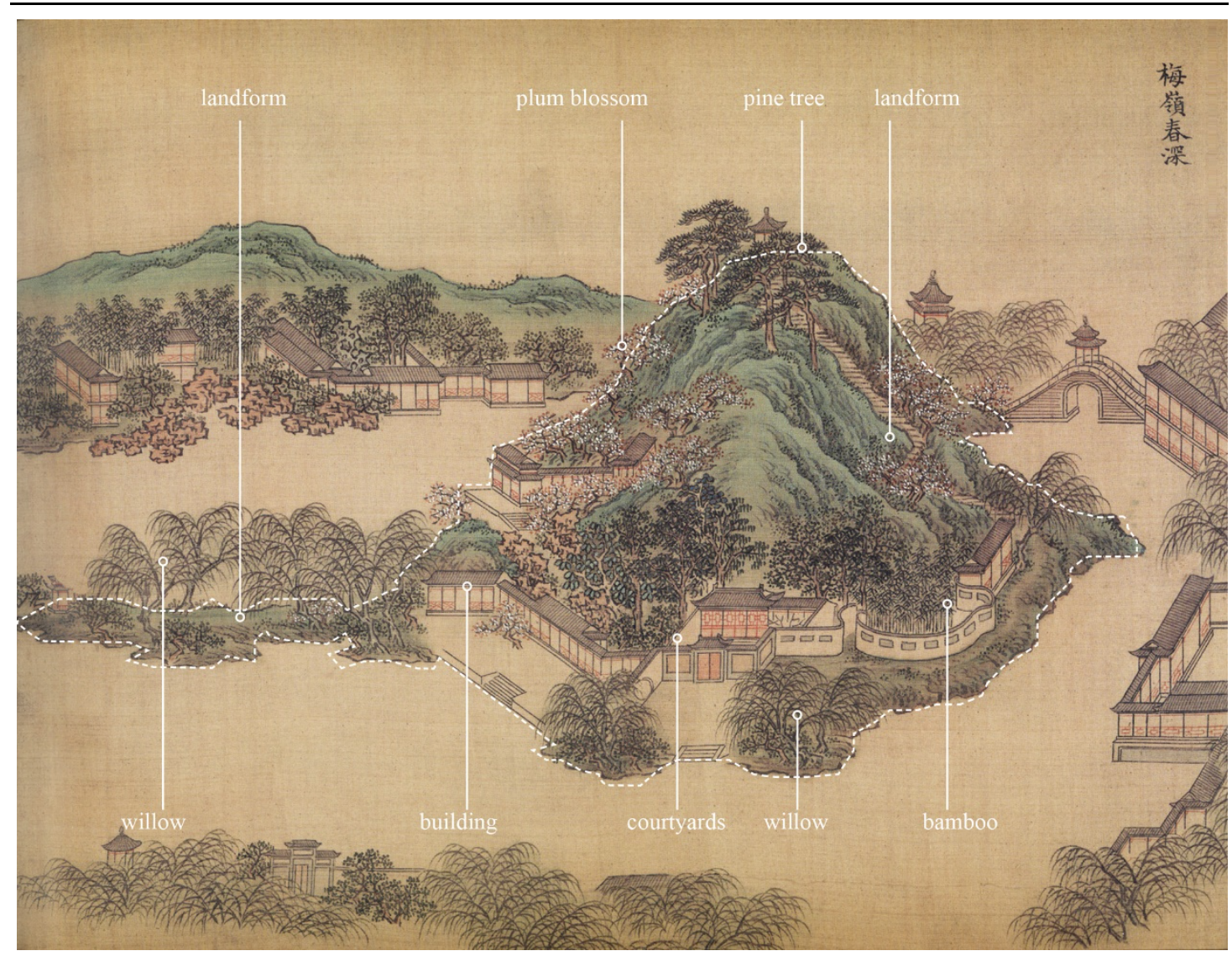

Figure 4. Identifying historic landscape features from historical paintings - the example of Meiling Chunshen (梅岭 春深) in the Atlas of Grant Landscapes of the Gardens in the South of the Yangtze River (江南园林胜景图册) in 1760

Secondly, in-depth interviews were conducted with key landscape stakeholders to reveal their understandings of authenticity. Five stakeholders within the management system were asked to point out the most important sites in Slender West Lake and give their own interpretations about these sites. The interview time of each stakeholder ranged from 40-60 minutes, depending on the content of the answers, and allowing each interviewee to fully express their own perceptions. Stakeholders in this research included a park manager, a local heritage expert, a landscape developer, a local landscape historian, and a commercial tour organiser. All these stakeholders had worked in Slender West Lake for more than 15 years. It is therefore reasonable to believe that their perspectives can reflect contemporary understandings 
of the landscape and its authenticity. Although tourists and residents are also important stakeholders, they do not directly undertake conservation and management works. Therefore, they were not included in the interview process. The interviews used two open-ended questions to minimise the interference to interviewees and try to make them fully express their understanding of the landscape. At the same time, the study did not directly ask questions containing the word "authenticity" to avoid getting too "official" answers. Some supplementary questions, such as "what do you mean by that?" and "why this is important?" were asked to produce more information. The interviews were audio recorded within the permissions of the interviewees and then the transcriptions were analysed with an NVivo 12.1 software (QSR International, Melbourne, VIC, Australia). Some qualitative methods, including open and axial coding, categorising, connection, and developing themes were used to analyse the interview data and to identify stakeholders' shared understandings of authenticity (Blaikie, 2000, p. 208).

Thirdly, the perspectives of authenticity identified from the first two phases were then being interpreted within the Chinese cultural and social context. In this phase, results from the site observations, document analysis and the in-depth interviews were triangulated to see if a perspective holds across several data types. Only those perceptions that are reflected in the conservation documents, interviews, and protection status can be considered as the current stakeholders' understandings. Description and active interpretation via content analysis methods have been used for interpreting authenticity in the Chinese context. The skill of analytic induction was also applied in this research, especially for interrogating the identified concept of authenticity. 


\section{4 | RESULT: UNDERSTANDING OF HISTORIC LANDSCAPES AND}

\section{CONCEPTS OF AUTHENTICITY}

The case study showed that some important historical characters of Slender West Lake have faded away under contemporary conservation practices. It was found that Slender West Lake had a mixture of a variety of characters during its prosperous time in the middle of the Qing dynasty (1755-1795 CE), including the characters of countryside areas, royal garden landscapes, a military moat landscape, literati garden landscapes and traditional market area on the marginal of the historic town. These 5-character types were demonstrated by more than 24 landscape character areas distributed along the watercourse. As the result of wars, the lack of maintenance, and the change of economic and social structures, Slender West Lake became a mostly ruined site and these historic characters did not exist when the conservation practice started in the 1960s. However, only 2 types of landscape characters were highlighted during the intense reconstruction practices over the past four decades - the characters of royal garden landscapes and literati garden landscapes. The site observations also found that the number of character areas has decreased from 24 to 18 . More than that, though, the pattern and feature of modern parks has been unconsciously embedded into the landscape of Slender West Lake, which has a significant impact to the historic characters.

The changes of landscape character in Slender West Lake was partly the result of contemporary conservation practices. In Slender West Lake, nearly all sites have been physically changed. Reconstruction and restoration were not seen as a problem, but always an approach for conservation. Among the 18 sites within the studied area, only one site has been 
maintained as its original condition. Some 6 sites were identified as "restored sites", which means they were restored based on certain amount of historic remnants. There were 8 sites being recognised as "reconstructions". These sites involved rebuilding the environment at its original location without including any historic remnants. There were 3 new sites identified in Slender West Lake, which were built for contemporary uses without any historical references. All these changes were made mainly after Slender West Lake was nominated as a national Scenic and Historic Interest Area in 1988, which could partly reflect the local understandings of authenticity.

The strong intention of reconstruction has also been identified from the history of Slender West Lake. The documentary evidence demonstrated that creative reconstruction has been practiced in Slender West Lake since the Song dynasty (960-1279 CE) when Ouyang Xiu built his private garden - Pingshan Hall (Mountain-Level Hall) - on Shugang Hill. Pingshan Hall has been periodically restored and reconstructed for more than 10 times in the history of Slender West Lake (Table 2). Every restoration included new additions or changes. However, the significance of Pingshan Hall has not been reduced. Indeed, quite the reverse, the accumulation of different meanings through continuous interpretation has made the site more important in the cultural context. However, while the tradition of creative reconstruction has still been practiced in Slender West Lake today, successful and meaningful reconstruction projects like Pingshan Hall are very rare.

Apart from the LCA results, stakeholders' understandings of authenticity identified from interviews could further explain the changes of landscape characters. The five stakeholders 
have different backgrounds and positionalities in the current conservation system, which has an important impact on their understandings and interpretations of authenticity. The park manager, the heritage planner and the developer were working in the administration team of the local government. The park manager came from a management background, and he was mainly responsible for the daily management of Slender West Lake as public spaces. The developer has an engineering background and he was mainly responsible for the renovation of scenic spots and the development of new infrastructures in the area. The heritage planner has a dual background in architecture and history. He understands the concepts of heritage conservation and the laws and regulations on cultural heritage. His role was to establish the conservation and management policies for Slender West Lake. The other two stakeholders, the historian and the tour organiser, were not the members of the administration team, but they worked closely with the local government. The historian was mainly working on local history of Yangzhou and Slender West Lake. He had written many publications related to the history of Slender West Lake and undertook professional consulting work for local government. The tour organiser was the head of a local tourism company, mainly engaged in the tourism projects in the Slender West Lake. This company provided services for tourists under government supervision.

Four perceptions of historic landscapes were identified from stakeholders' oral interpretations (Figure 5). Firstly, most stakeholders saw Slender West Lake as a cultural experience - each site symbolised different cultural meanings and values, and these meanings formed a complete cultural experience. The meanings and values were considered more important than the physical environment. In the interviews, for example, most stakeholders mentioned the 15 reflections of the moon under the Five Pavilion Bridge - one of the most 
attractive sites in Slender West Lake: "Because there are 15 archways under the bridge, so we could see 15 reflections of the moon in a full-moon night." However, it is impossible to see 15 reflections. This interpretation is simply a beautiful hope based on Chinese moon worship.

\begin{tabular}{|c|c|c|c|}
\hline \multicolumn{3}{|c|}{ PERCEPTION 1 LANDSCAPE AS CULTURAL EXPERIENCE } & \multirow[b]{2}{*}{$\begin{array}{l}\text { the life of Yangzhou } \\
\text { the landscape structure } \\
\text { the landscape character } \\
\text { the 'borrow scenery' } \\
\text { a picturesque landscape } \\
\text { appropriate meanings }\end{array}$} \\
\hline $\begin{array}{l}\text { It is the } \\
\text { expeience } \\
\text { of }\end{array}$ & $\begin{array}{l}\text { pondering on the past } \\
\text { the landscape structure } \\
\text { seeing southern Yangtze river } \\
\text { appropriated meanings } \\
\text { the 'borrowed scenery' [4] }\end{array}$ & $\begin{array}{l}\text { It is the } \\
\text { experience } \\
\text { of }\end{array}$ & \\
\hline & Ouyang Xiu and Sushi & & $\begin{array}{l}\text { a picturesque landscape } \\
\text { the landscape character } \\
\text { the sound of landscape }\end{array}$ \\
\hline
\end{tabular}

PERCEPTION 2 LANDSCAPE AS PROTECTED SITE

\begin{tabular}{|c|c|c|}
\hline \multirow[t]{5}{*}{ It is a } & $\begin{array}{l}\text { Scenic Area } \\
\text { National Cultural Relic } \\
\text { successful reonstruction }\end{array}$ & \\
\hline & & Historian \\
\hline & relic & Park Manager \\
\hline & $\begin{array}{l}\text { protected place } \\
\text { faild reconstruction site }\end{array}$ & $\begin{array}{l}\text { Tour Organiser } \\
\text { Developer }\end{array}$ \\
\hline & well-protected site & Heritage Planner \\
\hline
\end{tabular}

\begin{tabular}{cl} 
PERCEPTION 3 & LANDSCAPE AS TOURIS \\
\hline It is a (an) & $\begin{array}{l}\text { artwork exhibition setting } \\
\text { performance setting } \\
\text { ritual activity setting } \\
\text { religious events setting }\end{array}$
\end{tabular}

PERCEPTION4 LANDSCAPE AS HISTORIC EVIDENCE

\begin{tabular}{|c|c|c|c|}
\hline \multirow[t]{5}{*}{$\begin{array}{l}\text { It was the } \\
\text { place }\end{array}$} & $\begin{array}{l}\text { Caoyin compiled Complete } \\
\text { Tang Shi Poetry } \\
\text { Emperor Qianlong visted } \\
\text { Zhu Ziqing visited }\end{array}$ & \multirow[t]{5}{*}{$\begin{array}{l}\text { It is the } \\
\text { evidence of }\end{array}$} & \multirow[t]{5}{*}{$\begin{array}{l}\text { prosperity of Yangzhou } \\
\text { prosperity of Yangzhou }\end{array}$} \\
\hline & of classical 24 spots in Qing & & \\
\hline & $\begin{array}{l}\text { built by scholars of Qing } \\
\text { Emperor Qianlong visited }\end{array}$ & & \\
\hline & of classical24 spots in Qing & & \\
\hline & of classical 24 spots in Qing & & \\
\hline
\end{tabular}

Figure 5. Four perceptions of the historic landscape of Slender West Lake

Secondly, stakeholders also considered Slender West Lake as protected site. The term "protection" in the local conservation context meant that repair could return the landscape to its historical condition. In stakeholders' oral interpretations, the meaning of "well-protected examples" is to keep repairing and thus prevent the site from being ruined. For example, a 
completely reconstructed site - Yechun Garden - was described by many stakeholders as a “well-protected site" (Figure 6). Stakeholders also saw Slender West Lake as a tourism product or historic evidence. The landscape manager and landscape developer hoped to make Slender West Lake a clean and well-organised park - a good product for tourists. By contrast, the landscape historian only considered the historic relic from the Qing dynasty as valuable components. The originality of the historic evidence was regarded as the most important attribute of the landscape.

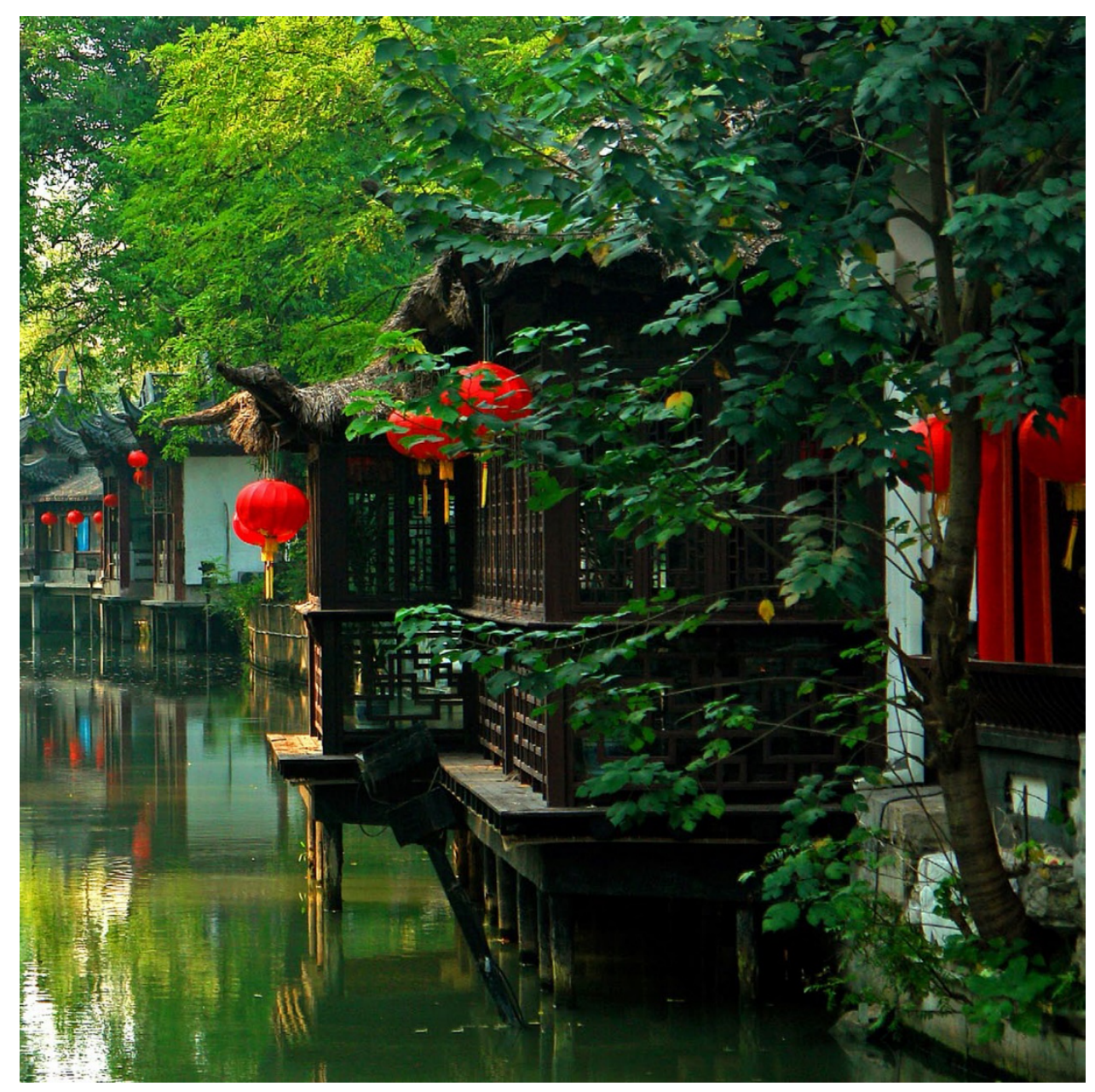

Figure 6. Yechun Garden, 2005, photographed by Jiansong Zhu

Overall, in stakeholders' interpretations of Slender West Lake, there were 55 "must see" sites, but none of these sites was a ruin with only original fabric (Figure 7). Among the "must 
see" sites, $51 \%$ were restored sites, and $31 \%$ were reconstructed sites, and only $18 \%$ were new sites. Therefore, the most preferred sites in Slender West Lake needed to include both original fabric and complete experiences. The site with only one aspect can rarely gain the highest preference (Figure 8). We can find traces of different models of authenticity from these interpretations, and the landscapes and sites described by various stakeholders had a shared pattern. There was a concern about the landscape's authenticity in Slender West Lake, but the specific form of existence needs further analysis.

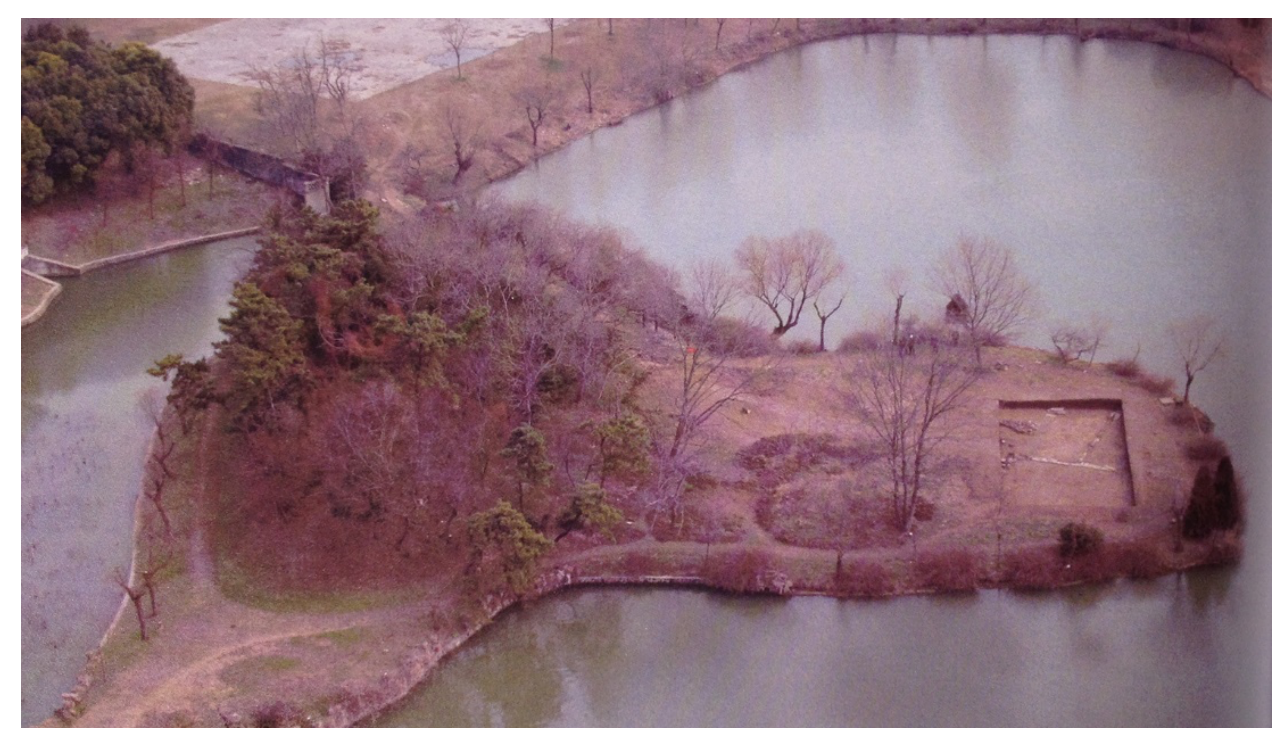

Figure 7. The only ruin site within the research area - Jiejiating Pavilion (接驾厅) (The hall to welcome the emperor) 


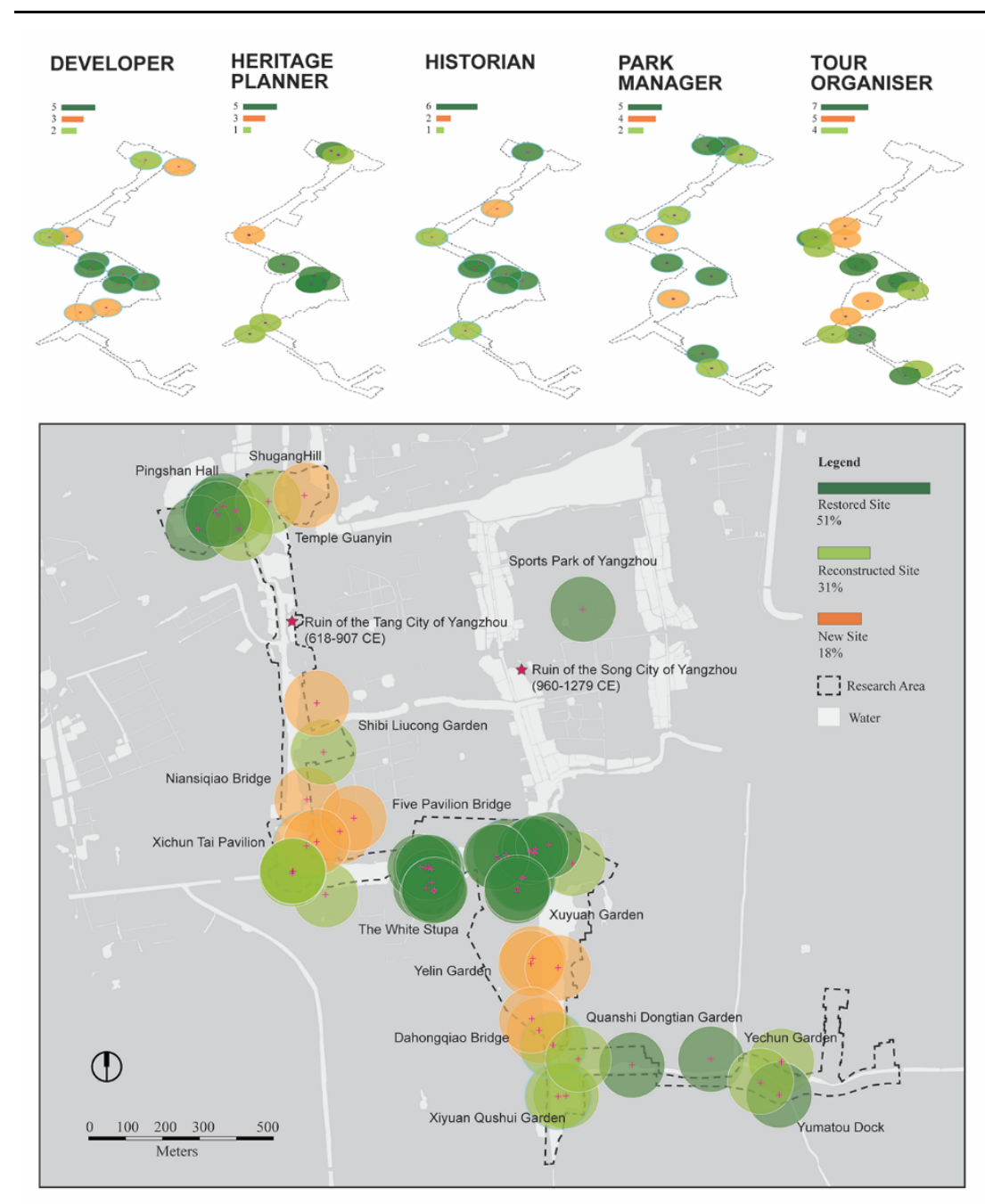

Figure 8 . The most preferred sites identified by stakeholders of Slender West Lake

\section{5 | Discussion: generating the local concept of authenticity}

The three model of authenticity, including material-based authenticity, value-based authenticity, and the New Heritage concept, were all identified from the case study of Slender West Lake. Firstly, the concept of cultural experience was aligned with the value-based authenticity, in which the intangible value was the main attribute of historic landscapes (Ahmad, 2006). The ability to provide a "complete landscape" and to demonstrate its historical values was concerned as the most important attribute of historic landscapes. In Slender West Lake, the 4 restored sites can still provide very meaningful experiences. 
Secondly, many sites in Slender West Lake were reconstructions or even new sites built mainly for residents and tourists. Many sites in Slender West Lake are still being used as urban green spaces or recreational areas for local people due to the high population density of Yangzhou. These examples might be interpreted as the reflection of the New Heritage concept. The concept of "protected site" and "tourism product" could also be interpreted by the New Heritage concept highlighting social engagement. Thirdly, while not every stakeholder believed it, there was still one interviewee maintaining that Slender West Lake contains historic evidence. The originality of historic fabric was concerned as the most important attribute. This concept was aligned with the material-based authenticity. The only one site protected in its original condition also demonstrated this model (Figure 7).

Although various stakeholders have expressed different views on authenticity, they have also shown full tolerance for the contradictions between different models. While stakeholders highlighted the originality of fabric, some reconstructed sites were also accepted if they could represent cultural meanings. Additionally, although most stakeholders appreciated the value of a complete landscape, only restored sites with original fabric were accorded the highest preference. The synthesis of these ideas demonstrated a dialectical culture in which members embrace dual aspects of the self and conceptualise the self as constantly changing (Peng \& Nisbett, 1999). This phenomenon was interpreted as a "naïve dialecticism" and it refers to a set of lay beliefs characterised by tolerance for contradiction, the expectation of change, and cognitive holism (Spencer-Rodgers et al., 2009). In the context of Slender West Lake, the local understanding of authenticity emphasised the cultural meanings of the landscape but without losing original fabric. Such attitude adopted all the suitable features from different theories that 
facilitate one's requirements, which was more subjective than objective.

The understanding of authenticity based on naïve dialecticism, or "dialectical authenticity", was not only affected by social factors, but also has its specific cultural contexts in China. The subjective attitude contained by dialectical authenticity has its deep roots in traditional Chinese culture. It was profoundly influenced by two native Chinese philosophies. Due to the impact of Confucianism, firstly, a landscape is a place for personal cultivation, because it contains the principle of human morality and personality. The purpose of travel in a landscape for a Chinese person was to learn and to consider the meaning of life, rather than to explore the landscape forms and their historic value per se (Gong, 2001). Secondly, due to the impact of Taoism, landscapes are valued for their aesthetic qualities rather than religious or scientific qualities (Lin, 2002; Han, 2006). Accordingly, the completeness of the landscape was considered important, rather than originality, since the cultural value and aesthetic value can hardly be perceived within a damaged landscape. In traditional landscape culture in China, the emphasis on intangible meanings, complete landscape and aesthetic values were based on a comprehensive and in-depth understanding of the landscape, including the history and status quo. Such understanding guaranteed the continuation of the cultural meanings and values in landscapes. Today, superficial applications of the subjective attitude without deep understanding of landscapes might cause negative impacts on landscape values and characters.

It was found that the dialectical authenticity also contained the material-based authenticity. However, the adoption of this model was explained as a product of international politics and globalisation. Over the past decades, China has endeavoured to catch up with international trends in every aspect (Fan, 2013; Qian, 2007). Heritage conservation practice in China has 
been integrated into the official rhetoric of modernisation (Qian, 2007). Heritage officials introduced internationally accepted conservation principles as a superior way to regulate heritage practices in China without paying enough attention on local heritage features (Qian, 2007). The material-based authenticity, as one of the fundamental international principles of heritage conservation, has been adopted in China as the national regulation. However, the Western attitude towards its past, truth and heritage contained by the material-based authenticity cannot be found in traditional Chinese culture (Derde, 2010). This was reflected by the situation that the ruined site in Slender West Lake was protected in its original condition but it was not valued by all stakeholders.

Creative reconstruction was one of the effective approaches to keep the rich meaning of historic landscapes in traditional Chinese culture. Creative reconstruction in Slender West Lake was mainly conducted by literati for cultural and social reasons. For example, most of the reconstructions of Pingshan Hall during the Ming and Qing Dynasties were made for commemorating Ouyang Xiu, an important Chinese literary master, and then the updated hall became a place for new owners' social activities. Creative reconstruction is different from conjecture as it is based on the understanding of the history and enough historical evidence. This cultural practice contributes to the historic dimension of a landscape and the continual character of a landscape through history. However, as an important cultural practice, creative reconstruction needs to be cautiously applied in contemporary conservation practices in China, as a comprehensive understanding and enough evidence can hardly be achieved today. The lack of historical evidence, knowledge, and landscape techniques may cause misunderstandings about the landscape and the breaking of historical context. 


\section{6 | CONCLUSION}

This article demonstrates that the concept of authenticity exists in the conservation of historic landscapes in China. The originality of fabric, the representation of cultural values, and the social engagement, were considered as three main indicators of authenticity, but choosing the appropriate indicator was highly influenced by specific social, political and economic powers. The dialectical authenticity and the attitude of naïve dialecticism identified in this article could better explain the conflicts between international conservation policies and local conservation practices in China. It has its deep roots in traditional Chinese culture and should be deemed as a cultural feature of historic conservation in China.

The interrogation of dialectical authenticity provided valuable implications for today's conservation of historic landscapes. Firstly, objective assessment and evaluation should be emphasised in contemporary conservation practices of historic landscapes in China. Scientific and systematic studies of historic landscapes could provide basic knowledge for maintaining the authenticity. Landscape Character Assessment guidance could be used in China as a major approach for the conservation of historic landscapes. Secondly, while there was a strong tradition of creative reconstruction in traditional Chinese culture, this tradition should be cautiously applied in contemporary conservation practices. The culture and social contexts have dramatically changed in China over the past century. Therefore, it is difficult to guarantee that the new construction could maintain the distinctive character and spirit of the historic landscape. Accordingly, to the cultural landscape theory, getting an agreement among a broader range of stakeholders might be an appropriate approach before any changes made in the landscape. 
Thirdly, it is dangerous to simply apply international regulations on authenticity to local historic landscapes without critical thinking. International principles should be interpreted and localised before applications.

\section{REFERENCES}

Ahmad, Y. (2006). The scope and definitions of heritage: From tangible to intangible, International Journal of Heritage Studies, 12(3), 292-300.

Araoz, G. F. (2011). Preserving heritage places under a new paradigm. Journal of Cultural Heritage Management and Sustainable Development, 1(1), 55-60.

Araoz, G. (2013). Conservation philosophy and its development: Changing understandings of authenticity and significance, Heritage \& Society, 6(2), 144-154.

Atwal, G. \& Williams, A. (2011). Is this Shangri-La? The case for authenticity in Chinese and Indian hospitality industry. Journal of Brand Management, 19(5), 405-413.

Blaikie, N. (2000). Designing social research: The logic of anticipation. Bodmin, Cornwall: Polity Press.

Chen, T. (2005). The main planning strategies of conserving the settings of the large - scale sites in the process of rapid urbanisation in China. The 15th ICOMOS General Assembly and International Symposium: Monuments and Sites in their Setting Conserving Cultural Heritage in Chaning Twonscapes and Landscapes, 17-21 Oct 2005, Xi'an, China [Conference or Workship Item]. Retrieved from http://www.icomos.org/xian2005/papers/3-14.pdf [Accessed 20/9/2019].

Clark, J., Darlington, J., \& Fairclough, G. (2004). Using Historic Landscape Characterisation, 
English heritage's review of HLC applications 2002-03. London: English Heritage \& Lancashire County Council.

Dawdy, S. L. (2009). Millennial archaeology. Locating the discipline in the age of insecurity. Archaeological Dialogues, 16(2), 131-207.

Denyer, S. (2005). Authenticity in World Heritage cultural landscapes: Continuity and change. In: J. L. Morales (Ed.), New views on authenticity and integrity in the World Heritage of the Americas. San Miguel de Allende, Guanajuato, Mexico: ICOMOS, IUCN. 5760.

Derde, W. (2010). Heritage and its cultural boundaries: Challenging the Western paradigm by means of the example of China. In: R. Amoeda, S. Lira, and C. Pinheiro (Ed.), Heritage 2010: Heritage and sustainable development. Barcelos: Green Lines Institute. 827-836.

Eetvelde, V. V., \& Antrop, M. (2004). Analyzing structural and functional changes of traditional landscapes - two examples from Southern France. Landscape and Urban Planning, 67(1-4), 79-95. Doi:10.1016/s0169-2046(03)00030-6.

Fairclough, G. (2001). Cultural landscape andspatial planning: England's historic landscape characterisation programme. Paper presented at the Historic Environment of the North Sea Inter Reg IIC Conference, South Shields.

Fairclough, G. (2009). New heritage frontiers. In: Council of Europe (Ed.), Heritage and beyond. Strasbourg, France: Council of Europe. 29-41.

Fan, L. (2013). International influence and local response: Understanding community involvement in urban heirtage conservation in China. International Journal of Heritage Studies, 20(6), 651-662. Doi:10.1080/13527258.2013.834834. 
Feng, S., \& Sha, R. (2007). A tentative study on the evaluation model of tourists' perception of the authenticity and satisfaction in ancient village tour 游客对古村落旅游的 “真实 感-满意度”测评模型初探. Human Geography, 06, 85-89.

Fojut, N. (2009). The philosophical, political and pragmatic roots of the convention. In: Council of Europe (Ed.), Heritage and Beyond. Strasbourg, France: Council of Europe. 13-22.

Gong, P. C. (2001). The history of the cultural spirit of travel 游的精神文化史论. Shijiazhuang: Hebei Education Press.

Han, F. (2006). The Chinese view of nature: Tourism in China's Scenic and Historic Interest Areas. (PhD), Queensland University of Technology, Brisbane.

Han, F. (2012). Cultural landscape: Marching on the way of exploration 探索前行中的文化 景观. Chinese Landscape Architecture, 05, 5-9.

Holtorf, C. (2006). Can less be more? Heritage in the age of terrorism. Public Archaeology, 5(2), 101-109.

ICOMOS (1964). International Charter for the Conservation and Restoration of Monuments and Sites (The Venice Charter 1964), Venice, Italy: International Council on Monuments and Sites.

ICOMOS (1994). The Nara Document on Authenticity. Charenton-le-Pont, France: International Council on Monuments and Sites.

Jerome, P. (2008). An introduction to authenticity in preservation. APT BULLETIN: Journal of preservation technology, 39, 2-3.

Khalaf, R. W. (2018). A proposal to apply the historic urban landscape approach to reconstruction in the World Heritage context, The Historic Environment: Policy \& 
Practice, 9(1), 39-52, doi: 10.1080/17567505.2018.1424615.

Kobyiński, Z. (2006). Protection, maintenance and enhancement of cultural landscapes in changing social, political and economical reality in Poland. In: L. R. Lozny (Ed.), Landscapes under pressure theory and practice of cultural heritage research and preservation. New York: Springer Science+Business Media, Inc. 213-242.

Lin, Y. (2007). Fundamental Research on Theories of Chinese Architectural Heritage Conservation 中国建筑遗产保护基础理论研究. (PhD), Xi'an University of Architecture and Technology, Xi'an.

Liao, R., Li, Q., Zhang, J., Lu, S., \& Qi, Q. (2009). Tourists' perceived study on the authenticity of urban historical blocks - Taking Confucius temple in Nanjing as an example 都市 历史街区真实性的游憩者感知研究——以南京夫子庙为例. Tourism Tribune, 01, $55-60$.

Lin, Y. T. (2002). My country and my people. Beijing: Foreign Language Teaching and Research Press.

Loulanski, T. (2006). Revising the concept for cultural heritage: The argument for a functional approach. International Jounral of Cultural Property, 13, 207-233.

Lowenthal, D. (1995). Changing criteria of authenticity. In: J. Jokilehto \& K. E. Larsen (Ed.), Nara Conferemce on Authenticity in Relation to the World Heritage Convention. Paris: UNESCO World Heritage Centre. 121-135.

Lu, Y. (2006). Historic preservation and the difficulty of authenticity 历史保护与原真性的困 惑. Journal of Tongji University (Social Science Section), 05, 24-29.

Macinnes, L. (2004). Historic landscape characterisation. In: K. Bishop \& A. Philips (Ed.), 
Countryside Planning: New Approaches to Management and Conservation. London: Earthscan. 155-169.

Mitchell, N. J. (1994). Evaluating authenticity of cultural landscapes: A perspective from the U.S. paper presented at the Nara Conference on Authenticity, Nara, Japan.

Peng, K. \& Nisbett, R. E. (1999). Culture, dialectics, and reasoning about contradiction. American Psychologist, 54, 741-754.

Poulios, I. (2010). Moving beyond a values-based approach to heritage conservation. Conservation and Management of Archaeological Sites, 12(2), 170-185.

Qian, F. (2007). China's Burra Charter: The formation and implementation of the China Principles. International Journal of Heritage Studies, 13(3), 255-264.

Skogheim, R., Simon, V. K., Gao, L., \& Dietze-Schirdewahn, A. (2018). Place identity with a historic landscape - An interview-based case study of local residents' relationship with the Austrått landscape in Norway, Heritage \& Society, 11(1), 1-18.

Rössler, M. (2008). Applying authenticity to cultural landscapes. Journal of Preservation Technology, 39, 2-3.

Ruan, Y. S. \& Lin, L. (2003). Authenticity in relation to the conservation of cultural heirtage 文化遗产保护的原真性原则, Tongji University Journal Social Science Section, 14(2), $1-5$.

Spencer-Rodgers, J., Boucher, H. C., Mori, S. C., Wang, L., \& Peng, K. (2009). The dialectical self-concept: Contradiction, change, and holism in East Asian cultures. Personality and Social Psychology Bulletin, 35(1), 29-44.

Starn, R. (2002). Authenticity and historic preservation: Towards an authentic history. History 
of the Human Science, 15(1), 1-16.

Stovel, H. (2007), Effective use of authenticity and integrity as World Heritage qualifying conditions. City \& Time, 2 (3): 3. Retrieved from http://www.ct.ceci-br.org [Accessed 25/5/2020].

Swanwick, C. (2002). Landscape Character Assessment Guidance for England and Scotland. Cheltenham; Edinburgh: The Countryside Agency; Scottish Natural Heritage.

Taylor, J. (2001). Authenticity and sincerity in tourism. Annals of Tourism Research, 28(1), 726.

Taylor, K. (2016). The Historic Urban Landscape paradigm and cities as cultural landscapes. Challenging orthodoxy in urban conservation, Landscape Research, 41(4), 471-480.

Trilling, L. (1972). Sincerity and Authenticity. London: Oxford University Press.

Turner, S. (2006). Historic Landscape Characterisation: A landscape archaeology for research, management and planning. Landscape Research, 31(4), 385-398.

UNESCO World Heritage Center (2017). Operational Guidelines for the Implementation of the World Heritage Convention. Paris, France: UNESCO World Heritage Centre, Intergovernmental Committee for the Protection of the World Cultural and Natural Heritage.

Yang, L., \& Wall, G. (2010). Authenticity in ethnic tourism: Domestic tourists' perspectives. Current Issues in Tourism, 12(3), 235-254.

Zhang, C. Y. (2010). A summary of heritage authenticity and integrity studies at home and abroad 国内外世界遗产原真性与完整性研究综述, Southeast Culture, 4, 30-37.

Zhang, Y., \& Dong, W. (2018). Determining minimum intervention in the preservation of 
heritage buildings, International Journal of Architectural Heritage, doi: $10.1080 / 15583058.2019 .1645237$.

Zhu, Y. J. (2015). Cultural effects of authenticity: Contested heritage practices in China. International Journal of Heritage Studies, 21 (6), 594-608. Doi: $10.1080 / 13527258.2014 .991935$.

\section{NOTES}

[1] State-listed Famous Historical and Cultural City is a national cultural heritage conservation program established by the State Council of the People's Republic of China in 1982. A State-list Famous Historical and Cultural City is a city or a district containing rich cultural heritage, and is of great historical and cultural significance. In 2015, there are 128 cities nominated as State-list Famous Historical and Cultural Cities.

[2] Anastylosis is an archaeological term for a reconstruction technique whereby a ruined building or monument is restored using the original architectural elements. It consists of returning fallen pieces of a building to their original position (ICOMOS, 1964).

[3] Scenic and Historic Interest Area (Scenic Area) is a designated national park system established by the Chinese Central Government since 1979. It is different from the National Park systems in Western countries as China's Scenic Areas are characterised by outstanding natural and cultural qualities. Today, an entire system of 250 Scenic Areas has been nominated at the national level.

[4] Borrowed scenery is the method of incorporating background landscape or landscape 
features into the composition of a garden found in traditional Chinese garden design. Here "the experience of the borrowed scenery" refers to the experience of Slender West Lake being regarded as an experience of the traditional Chinese garden. 
TABLE 1 Identifying the Historical Landscape Character of Slender West Lake - the example of Meiling Chunshen

\begin{tabular}{|c|c|c|c|c|}
\hline \multicolumn{3}{|r|}{ Historical Character } & \multicolumn{2}{|l|}{ Documentary evidence } \\
\hline \multicolumn{3}{|c|}{$\begin{array}{l}\text { Meiling Chunshen (梅岭春深) (The Plum Ridge in Deep Spring) was an artificial hill imitating the character of a } \\
\text { mountain. It was quiet and secluded. The plum blossom was the primary landscape. }\end{array}$} & $\begin{array}{l}\text { Li Dou, Yangzhou Huafang Lu (扬州画舫录) (Record } \\
\text { of the Painted Pleasure Boats of Yangzhou), } 1795\end{array}$ & $\begin{array}{l}\text { Local } \\
\text { chronology }\end{array}$ \\
\hline & & Contributing Landscape Features & \multicolumn{2}{|l|}{ Documentary evidence } \\
\hline \multirow{4}{*}{$\begin{array}{l}\text { Tangible } \\
\text { Features }\end{array}$} & Landform & $\begin{array}{l}\text { An island made from rocks and the soil dredged from the lake. Its elevation is } \\
18.21 \mathrm{~m} \text {, which is the highest viewpoint on the lake }\end{array}$ & $\begin{array}{l}\text { Yangzhou Huafang Lu (Record of the Painted } \\
\text { Pleasure Boats of Yangzhou) }\end{array}$ & $\begin{array}{l}\text { Local } \\
\text { chronology }\end{array}$ \\
\hline & $\begin{array}{l}\text { Spatial } \\
\text { Organisation }\end{array}$ & $\begin{array}{l}\text { Buildings are irregularly arranged at different positions of the hill, perfectly } \\
\text { belonging to the scenery to become a whole with it. The island is divided into } \\
\text { separated courtyards, and the designed magnifies the spaces through sequence and } \\
\text { depth, aiming to make visitors imagine the hill to be larger than it is }\end{array}$ & $\begin{array}{l}\text { Atlas of Great Landscapes of the Gardens in the } \\
\text { South of the Yangtze River (江南园林胜景图册) } \\
\text { (1760), the court painting of SWL during the south } \\
\text { inspection of Emperor Qianlong }\end{array}$ & Painting \\
\hline & Building & $\begin{array}{l}\text { Buildings were named for natural features which demonstrated the developer's } \\
\text { fondness for nature, such as Luyin Guan (Green Shade Pavilion) and Hushang } \\
\text { Caotang (Humble Cottage on the Lake) }\end{array}$ & $\begin{array}{l}\text { Zhao Zhibi, Pingshantang Tuzhi (平山堂图志) (An } \\
\text { Illustrated Record of the Mountain-Level Hall), } 1765\end{array}$ & $\begin{array}{l}\text { Historical } \\
\text { archive }\end{array}$ \\
\hline & Vegetation & $\begin{array}{l}\text { There are trees preferred by Chinese scholars as their stance and natural habits are } \\
\text { associated with temperaments or characteristics such as loftiness, chastity, and } \\
\text { tenacity. Plum blossom withstands the cold winter, pine trees are mighty and sturdy, } \\
\text { and bamboos are straight and jointed }\end{array}$ & $\begin{array}{l}\text { Some } 28 \text { poems about Meiling Chunshen composed } \\
\text { by literati scholars in the Qing dynasty. Traditional } \\
\text { plants and social activities were the main topics }\end{array}$ & Poem \\
\hline \multirow[t]{2}{*}{$\begin{array}{l}\text { Intangible } \\
\text { Features }\end{array}$} & Oral history & $\begin{array}{l}\text { The original developer, Cheng Zhiquan, spent three years with } 20,000 \text { workers on } \\
\text { the development of this island, but he failed, until one night he dreamed of Guan } D i \\
\text { who told him the methods of measuring the land and construction. He then built the } \\
\text { island in a few days }\end{array}$ & $\begin{array}{l}\text { Yangzhou Huafang Lu (Record of the Painted } \\
\text { Pleasure Boats of Yangzhou) }\end{array}$ & $\begin{array}{l}\text { Local } \\
\text { chronology }\end{array}$ \\
\hline & Imperial & Emperor Qianlong visited Slender West Lake in $1762,1765,1789$ and $1784 . \mathrm{He}$ & Atlas of Great Landscapes of the Gardens in the & Painting \\
\hline
\end{tabular}




\begin{tabular}{lll}
\hline \hline inspection & wrote two poems about this landscape & South of the Yangtze River \\
\cline { 2 - 3 } $\begin{array}{l}\text { Local folk’s } \\
\text { activity }\end{array}$ & $\begin{array}{l}\text { The gardens on the island were accessible to casual visitors. In the morning, visitor } \\
\text { could wander around and enjoy themselves. In the afternoon, the garden owners } \\
\text { would come to the gardens and invite guests along, or put on a theatrical } \\
\text { performance }\end{array}$ & $\begin{array}{l}\text { Wu Woyao, Bizarre Happenings Eye witnessed over } \\
\text { two Decades (二十年目睹之怪现状), 1909 }\end{array}$ \\
\hline
\end{tabular}


TABLE 2 Creative reconstructions of Pingshan Hall in the history of Slender West Lake

\begin{tabular}{|c|c|c|c|}
\hline Dynasty & $\begin{array}{l}\text { Year (Chinese era } \\
\text { name) }\end{array}$ & Construction & Landscape owners \\
\hline \multirow{8}{*}{$\begin{array}{l}\text { Song dynasty } \\
(960-1279 \mathrm{CE})\end{array}$} & 1048 (宋庆历八年) & Original construction & Ouyang Xiu (欧阳修) \\
\hline & 1061 (宋嘉祐初年) & Restoration & Liu Chang (刘敞) \\
\hline & 1063 (宋嘉祐八年) & $\begin{array}{l}\text { Renovation; addition of } \\
\text { Xingchun Platform (行春台) }\end{array}$ & Diao Yue (フ约) \\
\hline & 1174-1189 (淳熙年间) & Restoration & Zhao Zimeng (赵子濛) \\
\hline & 1174-1189 (淳熙年间) & Extension & Zheng Xingyi (郑兴裔) \\
\hline & 1195-1200 (庆元年间) & Addition of pillow groves & Mi Shidan (糜师旦) \\
\hline & 1210 (嘉定三年) & Restoration & Zhao Shishi (赵师石) \\
\hline & 1225-1227 (宝庆年间) & Restoration & Shi Yanzhi (史岩之) \\
\hline $\begin{array}{l}\text { Ming dynasty } \\
(1368-1644 \\
\text { CE) }\end{array}$ & 1573-1620 (万历年间) & Reconstruction & Wu Xiu (吴秀) \\
\hline \multirow{9}{*}{$\begin{array}{l}\text { Qing dynasty } \\
(1644-1911 \\
\text { CE) }\end{array}$} & 1662 (康熙元年) & Changing the hall to a temple & Local folks \\
\hline & 1673 (康熙十二年) & Reconstruction & Wang Maolin (汪惁麟) \\
\hline & 1673 (康熙十二年) & $\begin{array}{l}\text { Reconstruction of Xingchun } \\
\text { Platform (行春台); addition of } \\
\text { Chinese parasol trees }\end{array}$ & Jin Zhen (金镇) \\
\hline & 1675 (康熙十四年) & $\begin{array}{l}\text { Extension of the back plot of the } \\
\text { hall; building of Zhenshang } \\
\text { Mansion (镇赏楼); and } \\
\text { restoration of Xingchun Platform } \\
\text { (行春台) }\end{array}$ & Wang Maolin (汪惁麟) \\
\hline & 1736 (乾隆元年) & $\begin{array}{l}\text { Reconstruction: addition of } \\
\text { Luochun Hall (洛春堂); building } \\
\text { of Xiyuan Garden (西园) }\end{array}$ & Wang Yinggeng (汪应庚) \\
\hline & 1750 (乾隆十五年) & Extension & Bing Deyi (秉德益) \\
\hline & 1756 (乾隆二十一年) & Extension & Bing Deyi (秉德益) \\
\hline & 1761 (乾隆二十六年) & Extension & Bing Deyi (秉德益) \\
\hline & 1764 (乾隆二十九年) & Extension & Bing Deyi (秉德益) \\
\hline
\end{tabular}

